УДК 612(470+571)(092)“18/19”Павлов

Тетяна САВЧУК, Софія БОШТАН,

\section{Олена ЯСІНСЬКА}

Вищий державний навчальний заклад України «Буковинський державний медичний

університет», Чернівці (Україна),

http://physiology.bsmu.edu.ua

\section{Tetyana SAVCHUK,} Sofia BOSTAN,

Olena YASINSKA

Higher State Educational Establishment

of Ukraine «Bukovinian State Medical University»,

Chernivtsi (Ukraine)

Ключевые слова: И.П. Павлов, физиология, высшая нервная деятельность.

\section{ІВАН ПАВЛОВ: ОСОБИСТІСТЬ ЧЕРЕЗ \\ ПРИЗМУ НАУКОВИХ ЗДОБУТКІВ}

\title{
IVAN PAVLOV: THE PERSON THROUGH \\ A PRISM OF SCIENTIFIC ACHIEVEMENTS
}

Савчук Т., Боштан С., Ясинская О. Иван Павлов: личность сквозь призму научных достижений.

Иван Петрович Павлов - выдающийся ученый, гордость физиологической науки, «первый физиолог мира», как назвали его коллеги на одном из международных съездов. Ему была присуждена Нобелевская премия, его избрали почетным членом 130 академий и научных обществ.

«Это звезда, которая освещает мир, проливая свет на еще не изведанные пути», - говорил о нем Герберт Уэллс. Именно И. Павлова считают основателем науки о высшей нервной деятельности. Ученый создал наибольшую в России физиологическую школу и сделал ряд существенных открытий в области регуляции пищеварения.

Вступ. Іван Павлов - один з найяскравіших наукових авторитетів не тільки Росії, а й усього світу. Він зумів зробити значний внесок у розвиток психології та фізіології. Саме І. Павлова вважають засновником науки про вищу нервову діяльність людини. Вчений створив найбільшу в Росії фізіологічну школу і зробив ряд вагомих відкриттів у галузі регуляції травлення.

XX століття ознаменувалося новим етапом у розвитку фізіології, характерною рисою якого був перехід від вузького аналітичного розуміння життєвих процесів до ширшого - синтетичного. Величезний вплив на розвиток вітчизняної й світової фізіології зробили роботи I. Павлова та його школи по фізіології вищої нервової діяльності. Відкриття науковцем умовного рефлексу дозволило на об'єктивному підгрунті розпочати вивчення психічних процесів, що лежать в основі поведінки тварин і людини. Впродовж 35-літнього дослідження вищої нервової діяльності ним були встановлені основні закономірності утворення та гальмування умовних рефлексів, фізіологія аналізаторів, типи нервової системи, виявлені особливості порушення вищої нервової діяльності при експериментальних неврозах, розроблена кіркова теорія сну й гіпнозу, закладені основи вчення про сигнальні системи. Роботи I. Павлова заклали матеріалістичний фундамент для наступного вивчення вищої нервової діяльності, а також природничо-наукове обгрунтування теорії відображення.

У науковій діяльності І. Павлова, яка тривала бі- льше 60 років, чітко виокремлюються три періоди. Фундаментальні дослідження вченого були присвячені фізіології кровообігу, фізіології травлення i створенню нового розділу фізіології - вищої нервової діяльності. По фізіології кровообігу І. Павлов виконав 19 досліджень, які стосувалися проблем рефлекторної регуляції і саморегуляції кровообігу. Знаково, що в працях з фізіології кровообігу дослідник звертав увагу на психічний стан собак, як на одну з основних умов достовірності експерименту. В дослідженнях фізіології кровообігу І. Павловим були закладені основи системного підходу до вивчення фізіологічних функцій ${ }^{1}$.

Описуючи науковий шлях І. Павлова, варто відзначити найважливіші віхи його життя. Народився майбутній науковець 26 вересня 1849 р. в м. Рязані. В 1864-му році закінчив Рязанське духовне училище, після якого він вступає до семінарії. На останньому курсі I. Павлову потрапила книжка професора I. C€ченова «Рефлексы головного мозга». В 1870 році він вступив в Петербурзький університет на факультет юриспруденції, однак через декілька днів перевівся на одне із відділень фізико-математичного факультету. Закінчив Петербузький університет (1875р.) і Медико-хірургічну академію (1879р.), в якій розпочав наукову діяльність.

У 1881 році відбулась щаслива подія - Іван Петрович одружився на Серафимі Василівні Корчевській, від якої у нього народилась донька і четверо синів. Але десятиліття, яке так добре розпочалось, ста- 
ло найскладнішим для вченого і його сім'ї. Безкінечні переїзди на чужі квартири, важке нещастя - втрата двох синів, хвороба Серафіми Василівни - все це забирало сили, які були необхідні для наукових досліджень. Був час, коли мужність зрадила Івану Петровичу, він втратив надію на можливість змінити життя своєї сім'ї. I тоді саме дружина наполягла на тому, щоб І. Павлов ретельно займався дисертацією. Після тривалої боротьби з адміністрацією Військовомедичної академії, І. Павлов в 1883 році захистив дисертацію, яку присвятив опису нервів, що контролюють діяльність серця. Після захисту він отримав ступінь доктора медицини і був призначений приватдоцентом в академію, але відмовився від цього призначення в зв'язку із роботою в Лейпцигу з Гейденгайном і Карлом Людвігом, двома найбільш видатними фізіологами того часу. Через два роки І. Павлов повернувся в Росію. Потім він скупо, декількома фразами напише про важке десятиліття свого життя: «До професури в 1890 році, вже одруженому, з дітьми, в фінансовому плані було дуже сутужно. Врешті, на 41-м році життя, я отримав професуру, отримав власну лабораторію $<\ldots>$. Таким чином, раптом виявилось достатньо фінансів, і широка можливість робити в лабораторії, що хочеш».

До 1890 року праці І. Павлова отримали визнання вчених усього світу. 3 1891p. він - завідувач фізіологічного відділу Інституту експериментальної медицини, який був організований за його активної участі; одночасно І. Павлов залишався керівником фізіологічних досліджень у Військово-медичній академії, в якій пропрацював 31895 по 1925 рік.

Від народження І. Павлов був шульгою, як і його батько, він постійно тренував праву руку і в результаті настільки добре оволодів обома руками, що асистувати під час операцій йому було дуже важко «ніколи не було відомо, якою рукою він буде діяти в наступний момент. Він накладав шви правою і лівою рукою 3 такою швидкістю, що двоє асистентів не встигали подавати йому голки 3 шовним матеріалом» ${ }^{2}$

Систематичні дослідження в галузі фізіології травлення I. Павлов почав у 1894 році, коли на кошти А. Нобеля в інституті експериментальної медицини було відкрито перше в світі спеціальне операційне відділення для тварин. Операції на тваринах Павлов проводив в умовах, яких дотримувався хірург в клініці, тобто відповідний наркоз, ретельна чистота при операції, чисті приміщення після операції і дбайливий догляд за тваринами. Вчений застосовував при операціях всі досягнення медицини XIX століття: асептику, антисептику, наркоз (див. фото № 1). В кінці свого життя I. Павлов наполіг на встановленні відомого монументу - «Пам'ятник собаці», який розташований в Санкт-Петербурзі, на території парку Інституту експериментальної медицини Російської Академії медичних наук на Аптекарському острові (див. фото № 2).

Психологія того часу була пронизана ідеалістичними концепціями; їй був чужий принцип детермінізму, який I. Павлов вважав основою наукового пізнання. Багато психологів дотримувалися думки про свободу волі і незалежності свідомості від його матеріального субстрату - мозку; вони відривали психічне від фізіологічного. Це викликало в I. Павлова різко негативне ставлення до сучасної йому ідеалістичної психології, ідеологічні установки якої були йому органічно чужі і викликали у нього бурхливий протест. Дотримуючись матеріалістичного світогляду, дослідник розглядав думку, як функцію мозку і був впевнений в єдності психічного і фізіологічного.

До експериментального аналізу діяльності великих півкуль головного мозку І. Павлов підійшов за допомогою створеного ним методу умовних рефлексів. Рішення пояснити психічну діяльність в термінах рефлекторної діяльності вперше з'явилось у його доповіді «Об экспериментальной психологии и психопатологии на животных», виголошеній ним на міжнародному конгресі медицини в Мадриді, в 1903 році.

Для вивчення діяльності великих півкуль головного мозку І. Павлов вибрав слинну залозу, іiї діяльність ретельно кількісно вивчалась. В умовному рефлексі дослідник побачив механізм пристосування. Вражений силою умовних рефлексів, які проливають світло на психологію і фізіологію, він після 1902 року сконцентрував свої наукові інтереси на вивченні вищої нервової діяльності. В інституті, який був розташований недалеко від Петербургу, в містечку Колтуші (див. фото № 3), I. Павлов створив єдину лабораторію по вивченню вищої нервової діяльності. Її центром була відома «Вежа мовчання» - особливе приміщення, яке дозволяло розмістити піддослідних тварин в повну ізоляцію від зовнішнього світу. Досліджуючі реакції собак на зовнішні подразники, I. Павлов зробив було друге велике відкриття в галузі фізіологіі.

Відданий своїй справі і високоорганізований у всіх аспектах своєї роботи: операції, читання лекцій або проведення експериментів, І. Павлов відпочивав у літні місяці, і в цей час із захопленням займався садівництвом і читанням історичної літератури. Як згадує один із колег, «він завжди був готовий для радості і вбирав іiі з сотен джерел». Одним із захоплень вченого було розкидування пасянсів, він також любив розповідати анекдоти. Однак серед них не було таких історій, які б свідчили про його академічну розсіяність. Він був дуже акуратним і точним науковцем ${ }^{3}$.

Становище великого російського вченого захищало його від політичних колізій, на які були багаті революційні події в Росії на початку XX ст. Так, після встановлення радянської влади був виданий спеціальний декрет за підписом Леніна про створення умов, які забезпечували роботу І. Павлова. Це було досить дивним, тому що більшість науковців була під наглядом державних органів, які нерідко втручались в їхню наукову роботу. Більшовики платили золотом за дорогу закордонну апаратуру, яка була необхідна вченому для наукових експериментів, дозволяли йому закордонні відрядження. При цьому І. Павлов більшовиків не любив і не приховував цього. В його кабінеті висів портрет принца 
Ольденбургского, який у 1890 р. профінансував створення цього закладу, а ось на зображення Леніна і Сталіна корифей науки вказував і говорив своїм: «Ось через кого ми погано живемо!». Науковець приходив на офіційні радянські прийоми 3 повним набором царських нагород на грудях, а коли у Військово-медичній академії оголосили «чистку» студентів «за походженням», І. Павлов відверто заявив, що він - син священика. Йому все прощали. Секрет був простим - більшовики не могли арештувати першого фізіолога світу, а крім того їх зацікавили «наукові методи ведення слідства». До епохи «великого терору» I. Павлов не дожив - помер у лютому 1936 р. Про його смерть залишилася така легенда: коли I. Павлов зрозумів, що помирає, він скликав учнів і став диктувати їм свої відчуття, а тут в квартиру постукав незапланований відвідувач, його спровадили зі словами: «Академік Павлов зайнятий. Він помирає».

При оцінці значення теорії І. Павлова про мозкову діяльність для сучасної нейрофізіології, багато положень наразі є застарілими (уявлення про гальмування в корі великих півкуль тощо), але загальні положення теорії (концепція взаємовідносин кіркових і підкіркових структур, ідея підкріплення як основи умовнорефлекторної регуляції мозкової діяльності) повністю зберігають своє значення методологічної основи об'єктивного підходу до основних питань роботи мозку. Як і будь-яка інша наукова теорія, вчення I. Павлова не може розглядатись як абсолютна істина, саме іiї застосування передбачає подальший розвиток.

\section{Reference:}

${ }^{1 .}$ W. Boldyreff. Academician I. P. Pavlov. / W. Boldyreff // American Journal of Digestive Diseases and Nutrition. - 1934. - 1 (9). - S. 747-754.

2. Asratyan Э.A. Yvan Petrovych Pavlov. Zhyzn', tvorchestvo, sovremennoe sostoyanye uchenyya. - M.: Nauka, 1981.

${ }^{3}$ Rezhym dostupu: http://www.uadoc.zavantag.com/ text/33550/index - 1.htm

Savchuk T., Boštan S., Yasynskaya O. Ivan Pavlov: the Person Through the Prism of Scientific Achievements. Ivan Petrovich Pavlov - the oustanding scientist, pride of physiological science, «the first physiologist of the world» as have named his colleagues on one of the international congresses. The Nobel Prize has been awarded him, he have selected the honorary member of 130 academies and scientific organizations. «It is a star which shines the world, throwing light on yet not experienced ways», - Gerbert Wells spoke about him. Павлова count the founder of science about the higher nervous activity. The scientist has created the greatest in Russia physiological school and has made a number of essential opening in the field of regulation of digestion.

In XX century began a new stage developments of physiology which characteristic feature transition from narrow understanding of vital processes up to synthetic was. Huge influence on development of Pavlov's physiology and have made his schools on physiology of the higher nervous activity. Opening by Pavlov of a conditioned reflex has allowed to start on an objective basis studying mental processes which underlie be- haviour of animals and the person. Pavlov's laws of formation and braking of conditioned reflexes are established, the physiology of analyzers, types of the higher nervous activity, are revealed features of infringement of the higher nervous activity at experimental neurosises, the brain theory of dream and hypnosis are developed, doctrines about alarm systems are incorporated. Works Павлова have created the materialistic base to the following studying the higher nervous activity, they give a nature-scientific substantiation of the theory of display.

Key words: I. Pavlov, physiology, the higher nervous activity.

Савчук Тетяна - кандидат медичних наук, доцент кафедри фізіології ім. Я. Кіршенблата ВДНЗ України «Буковинський державний медичний університет». Коло наукових інтересів: історія медицини, історія фізіології, нейродегенеративні зміни на тлі розвитку иукрового діабету, патофізіологія иукрового діабету. Автор біля 20 наукових статей та публікацій.

Savchuk Tetiana - PhD, Associate Professor of Physiology. J. Kirshenblata Higher State Educational Establishment of Ukraine "Bukovinian State Medical University." Author of 20 scientific articles. Research interests: history of medicine, pathogenic factors influence on the structure and function of the human nervous system and diabetes.

Боштан Софія - асистент кафедри фізіології ім. Я. Кіршенблата ВДНЗ Украйни «БДМУ». Коло наукових інтересів: історія медицини, історія фізіології, нейродегенеративні зміни на тлі розвитку иукрового діабету, патофізіологія иукрового діабету. Автор біля 10 науко вих статей та публікаиій.

Boshtan Sofiia - assistant of department of physiology named after Y. Kirshenblata of BSMU. Cohe author of 10 scientific articles. Research interests: history of medicine, pathogenic factors influence on the structure and function of the human nervous system and diabetes.

Ясінська Олена - кандидат медичних наук, доцент кафедри фізіологї ім. Я. Кіршенблата ВДНЗ Украйни «Буковинський державний медичний університет». Керівник відділення медицини Буковинської Малої академії наук. Автор біля 80 наукових статей та публікацій. Коло наукових інтересів: історія медицини, історія фізіології, гіпоксія і їі вплив на внутрішні органи.

Yasinska Elena - PhD, Associate Professor of Physiology. J. Kirshenblata Higher State Educational Establishment of Ukraine "Bukovinian State Medical University." Head of Department of Medicine Bukovinian Junior Academy of Sciences. Author by of 80 scientific articles. Research interests: history of medicine, hypoxia and its effect on the internal organs.

Received: 14-06-2016

Advance Acces Publischer: July 2016

(C) T. Savchuk, S. Boštan, O. Yasynskaya, 2016 


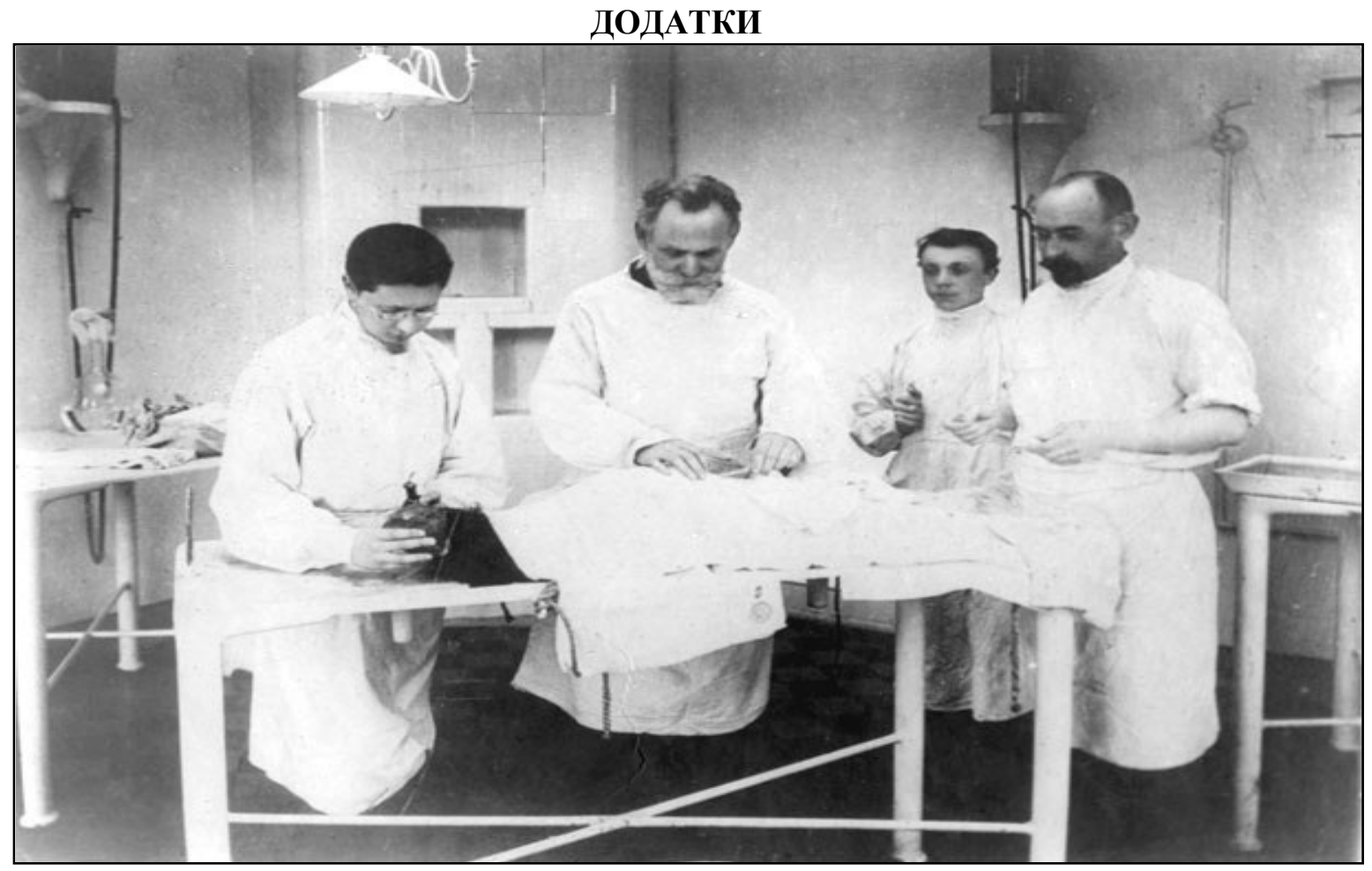

Фото №1. Операція (1904р.) в першій в світі операційній для тварин, яка була збудована в 1894 p.

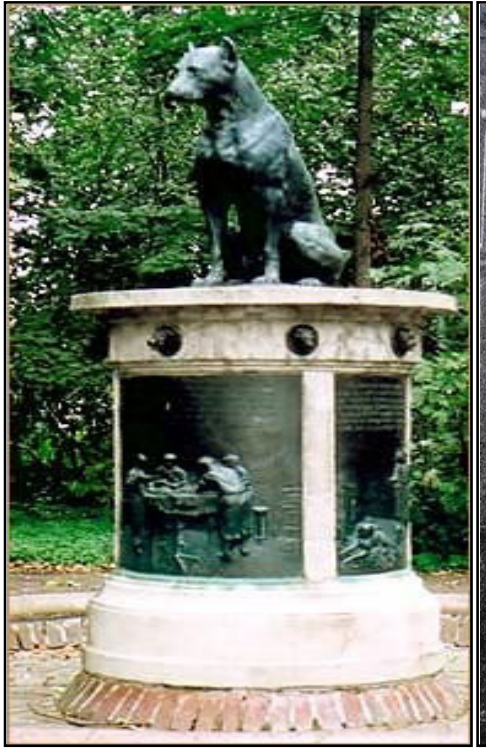

Фото № 2. «Пам'ятник собаці» в Санкт-Петербурзі, на території парку Інституту експериментальної медицини Російської Академії медичних наук на Аптекарському острові

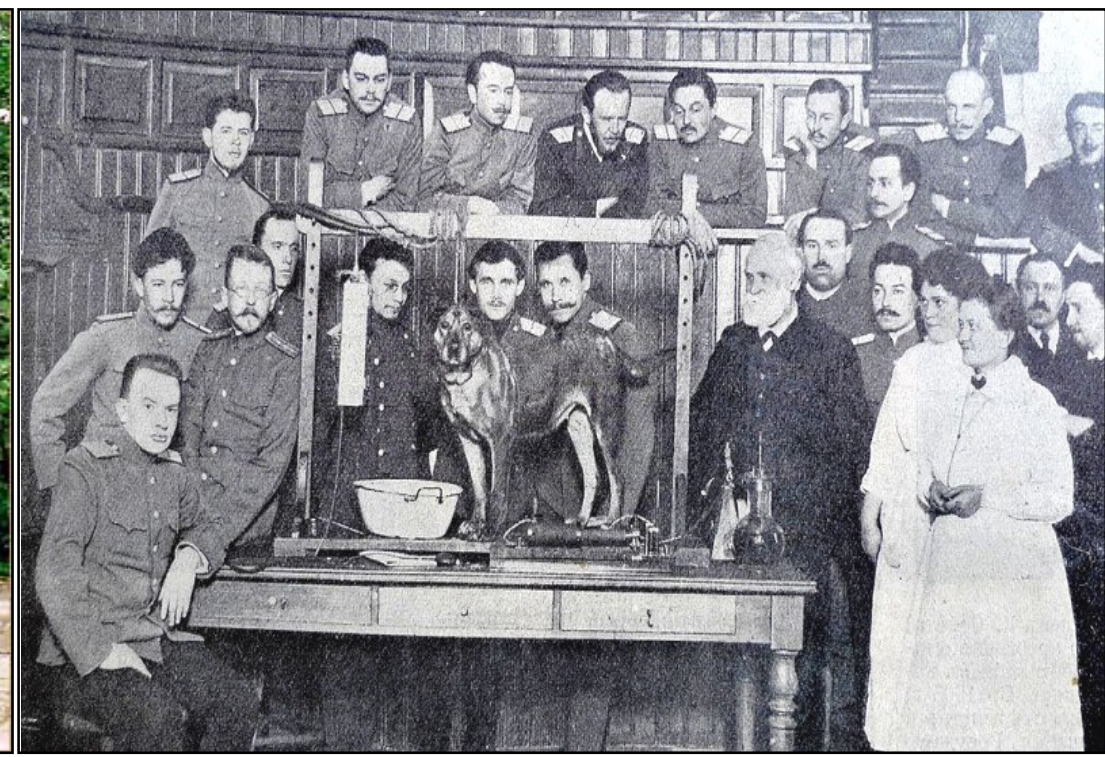

Фото № 3. І. П. Павлов в своїй лабораторії в містечку Колтуші 